\title{
GEOMORPHOSITES ASSESSMENT OF LORESTAN PROVINCE IN IRAN BY COMPARING OF ZOUROS AND COMANESCU'S METHODS (CASE STUDY: POLDOKHTAR AREA, IRAN)
}

\author{
Mehran MAGHSOUDI* \\ University of Tehran, Faculty of Geography, \\ Enghelab Avenue, Tehran, Iran, e-mail: maghsoud@ut.ac.ir
}

Maryam RAHMATI

University of Tarbiat Modares, Faculty of Humanities, Department of Physical Geography, Jalal Al-Ahmad Avenue, Nasr, Tehran, Iran, e-mail: maryam.rahmati@modares.ac.ir

\begin{abstract}
Citation: Maghsoudi, M., \& Rahmati, M., (2018). GEOMORPHOSITES ASSESSMENT OF LORESTAN PROVINCE IN IRAN BYCOMPARING OFZOUROS AND COMANESCU'S METHODS (CASE STUDY: POLDOKHTAR AREA, IRAN).GeoJournal of TourismandGeosites, 21(1),226. https://doi.org/10.30892/gtg.21118-283
\end{abstract}

\begin{abstract}
With complex geology and different geomorphology structure, climatic diversity, numerous islands and spiral coastline, Iran offers great variety of natural landscapes. This paper discusses a comparative assessment of geomorphosites located within the Poldokhtar area using Zouros and Comanescu methods. In this study based on field trips, Geomorphological values were evaluated and compared using six criteria in Zouros method and five criteria in Comanescu method. After identifying 37 geomorphosites in the region, 13 were selected based on the principal characteristics and added value. The assessment results showed that geomorphosites of this region can be divided into two main groups. The first groups are based on Comanescu method which consisted of five sites with high total value and the second group consists of eight sites with average value. In Zouros method the first group consisted of four sites with high value and the second groups are nine sites with average value. In order to protect identified geomorphosites and ensure appropriate management, the establishment of Seymare protected area is proposed. This proposal consists of a collection of diverse and spectacular geomorphosites.
\end{abstract}

Key words: Geomorphosites, Zouros and Comanescu's Methods, Compare Methods, Lorestan Province

\section{INTRODUCTION}

In recent years, academic community has focused on geotourism more than ever (Maghsoudi et al., 2013). In fact geotourism is viewed as promoting tourism to geosites (geomorphosites), the conservation of geodiversity, and an understanding of Earth sciences through appreciation and learning (Dowling, 2013). Geotourism particular importance today is that many government programmes aim to conserve the most valuable sites (geoconservation) and raise societal awareness about the importance of

\footnotetext{
* Corresponding author
} 
geodiversity (Newsome \& Dowling, 2017). Geotourism is now being practised all around the world. It has been promulgated for a whole range of places from specific sites and landscapes (e.g., Derbyshire, UK; Cope, 2016); urban areas (e.g., Hong Kong; Ng et al., 2010; Jeli District, Kelantan, Malaysia; Adriansyah et al., 2015); to regions (e.g., Bojnoord County, Iran; Kharazian, 2015; Faiyum Oasis, Egypt; Sallam et al., 2018, Kurkur-Dungul, Egypt; Sallam et al., 2018); and countries (e.g., European Union; Komossa et al., 2018).

Geomorphosites are defined "Geomorphological landforms and processes that have acquired aesthetic, scientific, cultural- historical and social- economic values due to human perception of geological, geomorphological, historical and social factors" (Pralong, 2005, Panizz, 2001, Reynard \& Panizza, 2005). Geomorpholosites play an important role in perception the paleo geomorphology evolution of an area (Comenescu et al., 2011). In recent decades, the vulnerability of the geoheritage that includes geological and geomorphological natural elements have been less considered in comparison with the biological and cultural heritage and thus its situation is constantly blurred in the conservation actions (Reynard \& Coratza, 2007). These geomorphological sites in the literature have been introduced with titles such as geomorphological assets (Panizza \& Piacente, 1993), geomorphological goods (Cartoon, 1994), geomorphological places (Hooke, 1994), geomorphological geotopes (Grandgirard, 1997). Places with geomorphological appeal (Panizza, 2001; Reynard et al., 2007). Geomorphological sites are important from special aspects. Some people like Grandgirard (1997) know its importance in identifying the chronicle and reconstruction of the Earth' history and some others like Panizza (2001) Panizza and Piacente (1993) consider these places not only from the scientific point of view, but also from other points that are related to ecology, economy and culture. However, these scientific values must be prioritized and other important values be placed in the next level.

During the last two decades, the quality of geomorphological heritage has been considered in terms of topics such as environmental impact assessment (Rivas et al., 1997; Coratza \& Giusti, 2005, Geneletti \& Dawa, 2009), natural heritage sites (Serrano \& Gonzalez Trueba, 2005), the promotion of tourism (Pralong, 2005), the management of natural parks and geoparks (Pereira et al., 2007, Zouros, 2007), scientific evaluation and understanding of the tourist (Comanescu et al, 2011) and the geological heritage (Rocha et al., 2014). Certainly, the used geomorphologic methods should be adapted to the system, process and geomorphological phenomena of the desired location and have features that could explain geomorphic characteristics. The link between anthropogenic activities and use of geological values should enhance the sustainable development of planning policies based on geoconservation and geointerpertation concept (Henriques et al., 2011).

Lorestan province offers a unique collection of attractive natural landforms owing to its geological and geomorphological diversity and its multiplicity of morphoclimatic zones due to difference in altitude $(220-4150 \mathrm{~m})$. This diversity has caused that Lorestan has been known as one of the choices of geotourism spot of Iran in 2014 according to Department Tourism and Cultural Heritage of Iran (General department cultural heritage of Lorestan province) and its tourism areas has been identified more than before for special protection. Since most of the geotourism attractions of Lorestan province are concentrated in southwestern part, so its different geomorphosites are known as tourist destinations of the region. To date, the conservation and management value of the geomorphosites has been less considered in the management and education; especially in this context has not been a comprehensive research in the form of articles and books.

So reliable geomorphosites assessment methods in this area can help to emphasize their value and their importance as locations with potential for conservation, research and management. These initiatives schemes based on geomorphological sites assessment in 
this region allow the local communities to gain experience and have active participation in geoconservation and geoheritage management. The aim of this study is comparison of geotourism development potential of geomorphological sites in Poldokhtar country, based on education and tourism potential, through evaluation of them and providing appropriate solutions for protection and promoting of this place as a tourism destination.

\section{STUDY AREA}

Study area with $47^{\circ} 57^{\prime}-48^{\circ} 28^{\prime} \mathrm{E}$ and $33^{\circ} 03^{\prime}-33^{\circ} 46^{\prime} \mathrm{S}$ is located in Lorestan province in the southwestern of Iran, which forms part of the central Zagros mountains with northwest - southeast direction (Figure 1).
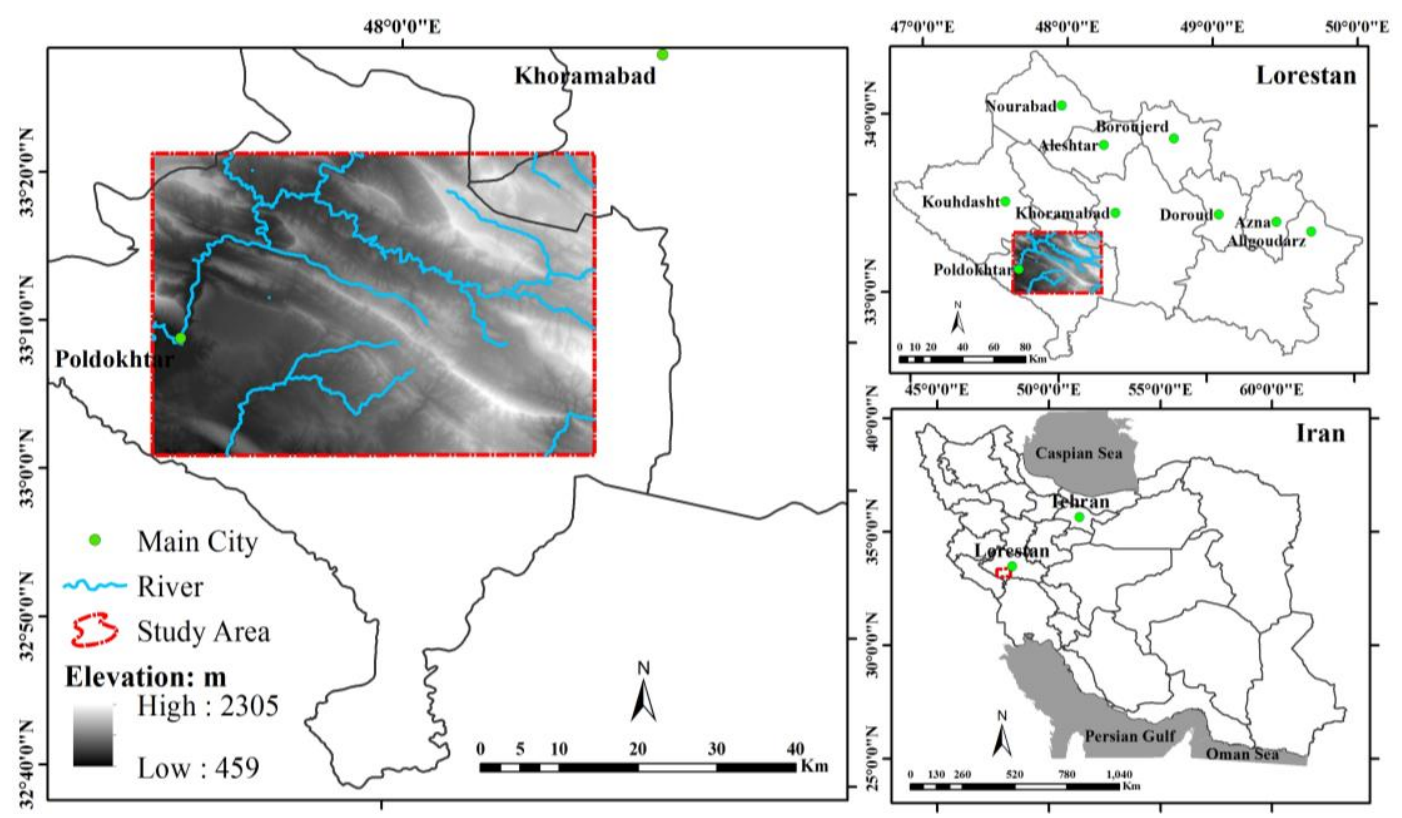

Figure 1. Geographical location of study area

Based on figure 2 and table 1 more landforms of region have been formed on Gachsaran formations with chalk marl and anhydrite and clay, Asmari - Shahbazan formation with dolomitic limestone and midlayers of marl and clay and Quaternary recent alluvium and debris (Ahmadabadi \& Rahmati, 2016). Volcanic and metamorphic activities have not been observed in the study area. Overall, in study area three typical topographic units can be seen. Mountain unit, which matches to the anticlines that caves such as Kowgan and Kalmakare have located on them; hill unit that are seen in erosion valleys and the syncline, typical example in this forms are erosional hogback near Afrine waterfall and Jaydar lake terraces. Typical Plain and flat lands unit in this area are located in the south and southwest, near 11 ponds and Pol Tang. 13 geomorphosites in the study area (Seymare landslide, Fanni - Laylomcluse (gorge -like features), 11 ponds of Poldokhtar, canyons and valleys of Pol Tang, Jaydar and Saymare lake terraces, the Kowgan man made cave, the Klmakare cave (the sixth world great treasures), the Vashian and Afrine waterfalls, typical Afrine Hogbacks, the Kashkan river meanders, the Takht e Narm rocky village, the Gavmishan geomorphosites collection (historical/ ancient bridges, karstic forms, sandstone Precipices) are geotourism locations that have been selected for this study. 
Geomorphosites Assessment of Lorestan Province in Iran by Comparing of Zouros and Comanescu's Methods (Case Study: Poldokhtar Area, Iran)

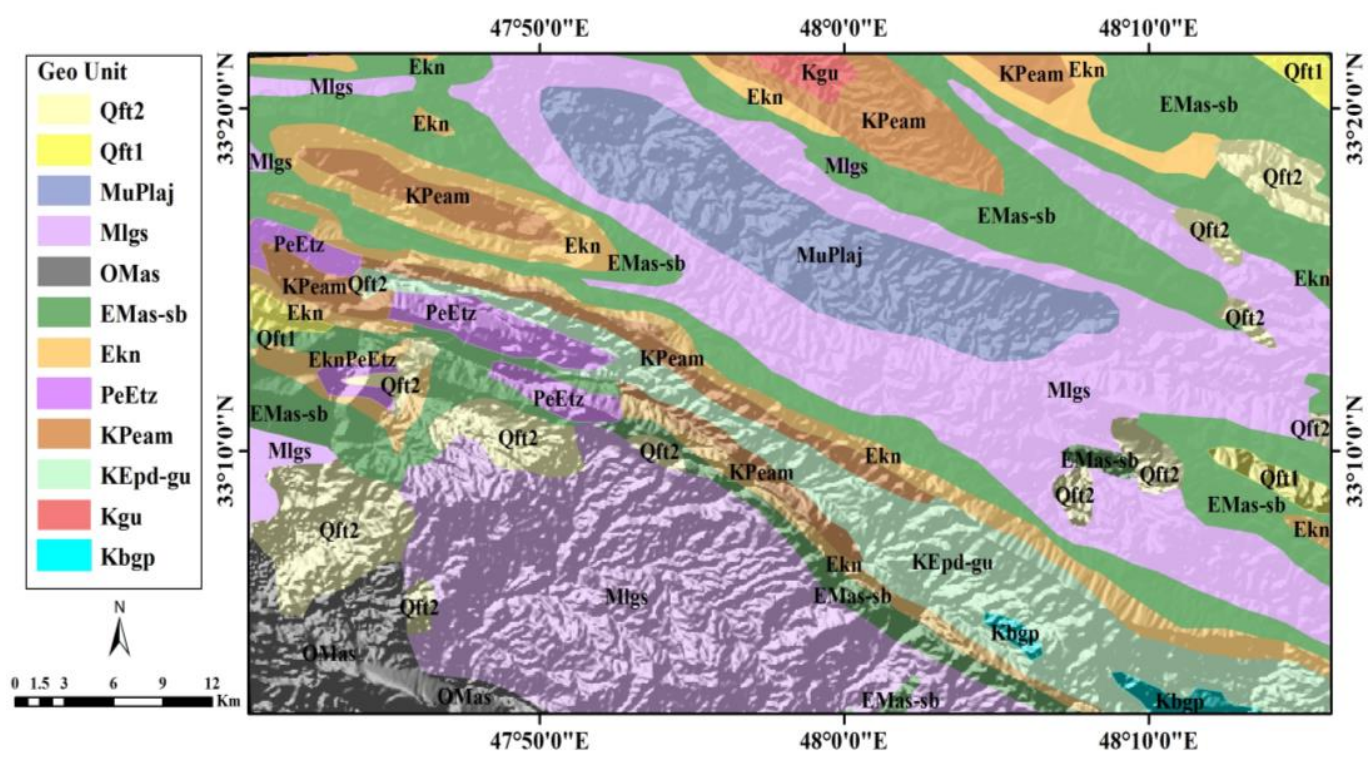

Figure 2. Geological unit's map in the study area provided from geological survey of Iran (1:100,ooo scale)

Table 1. Geological units table of the study area

\begin{tabular}{cll}
\hline Num & $\begin{array}{l}\text { Geo } \\
\text { Unit }\end{array}$ & Description \\
\hline $\mathbf{1}$ & Qft2 & Low level piedmont fan and valley teraces deposite \\
$\mathbf{2}$ & Qft1 & High level piedmont fan and valley terrces deposits \\
$\mathbf{3}$ & MuPlaj & Calcareous, sandstone, gypsum - veind, marl and siltstone \\
$\mathbf{4}$ & Mlgs & Anhydrite, salt, marl alternating with anhydrite, argillaceous limestone and \\
$\mathbf{5}$ & OMas & limestone \\
$\mathbf{6}$ & EMas-sb & Limestone with intercalations of shale \\
7 & Ekn & Conglomerate, sandstone and siltstone \\
$\mathbf{8}$ & PeEtz & Massive fossiliferous limestone \\
$\mathbf{9}$ & KPeam & Siltstone and sandstone with local development of chert conglomerate and \\
$\mathbf{1 0}$ & KEpd-gu & Mhelly limestone \\
$\mathbf{1 1}$ & Kgu & Marl and shale \\
$\mathbf{1 2}$ & Kbgp & Limestone and shale \\
\hline & &
\end{tabular}

Figures 3 to 7 shows the view of some geomorphosites of the study area. Some geomorphosites of this region have a special important; for example, Seymare landslide has been known "as the largest known landslide" (Bloom, 1978; Bargrizan, 1996) and "the biggest eastern hemisphere landslide" (Fisher, 1968) because of its extent and specific characteristics. Klmakare historical cave due to having a large number of antique objects dating to the Elamite civilization in the $1000 \mathrm{BC}$, has been called as "the sixth great world treasures" (Mahboubian et al., 2003, Khosravi \& Mousavi, 2014; Bashash, 2000; Parhan, 2014). Kowgan two-store cave is one of the few man- made caves related to the Parthian civilization (250 BC) that has been carved in the Zagros Mountains (Administration Cultural Heritage Handicrafts and Tourism OF the Lorestan Province, 2010). 


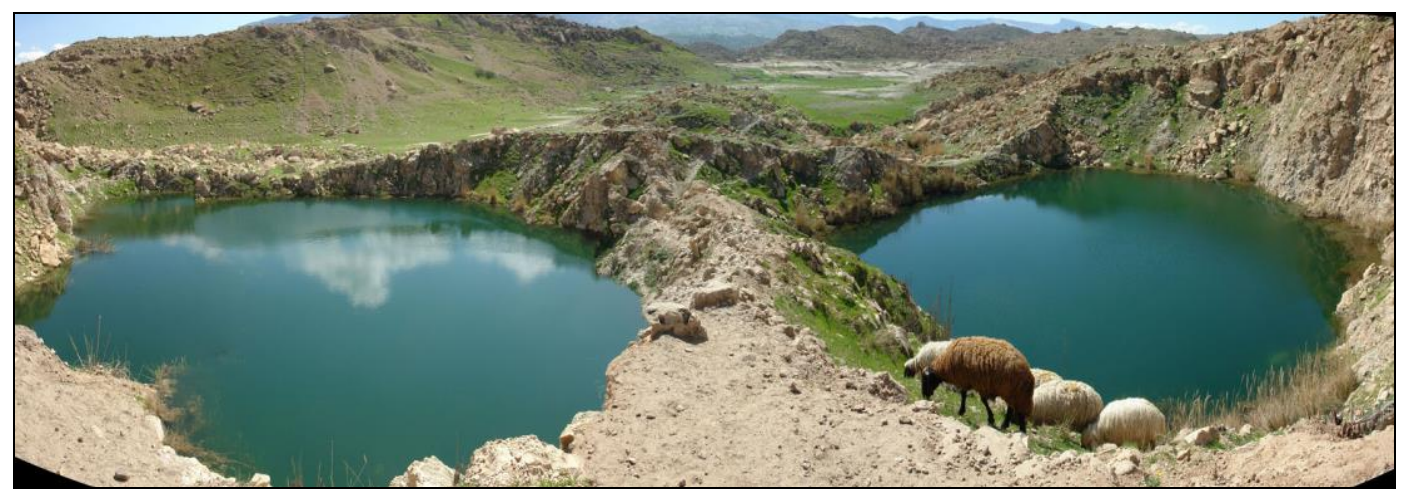

Figure 3. The view from the twin ponds (Lefone), part of the ponds Poldokhtar

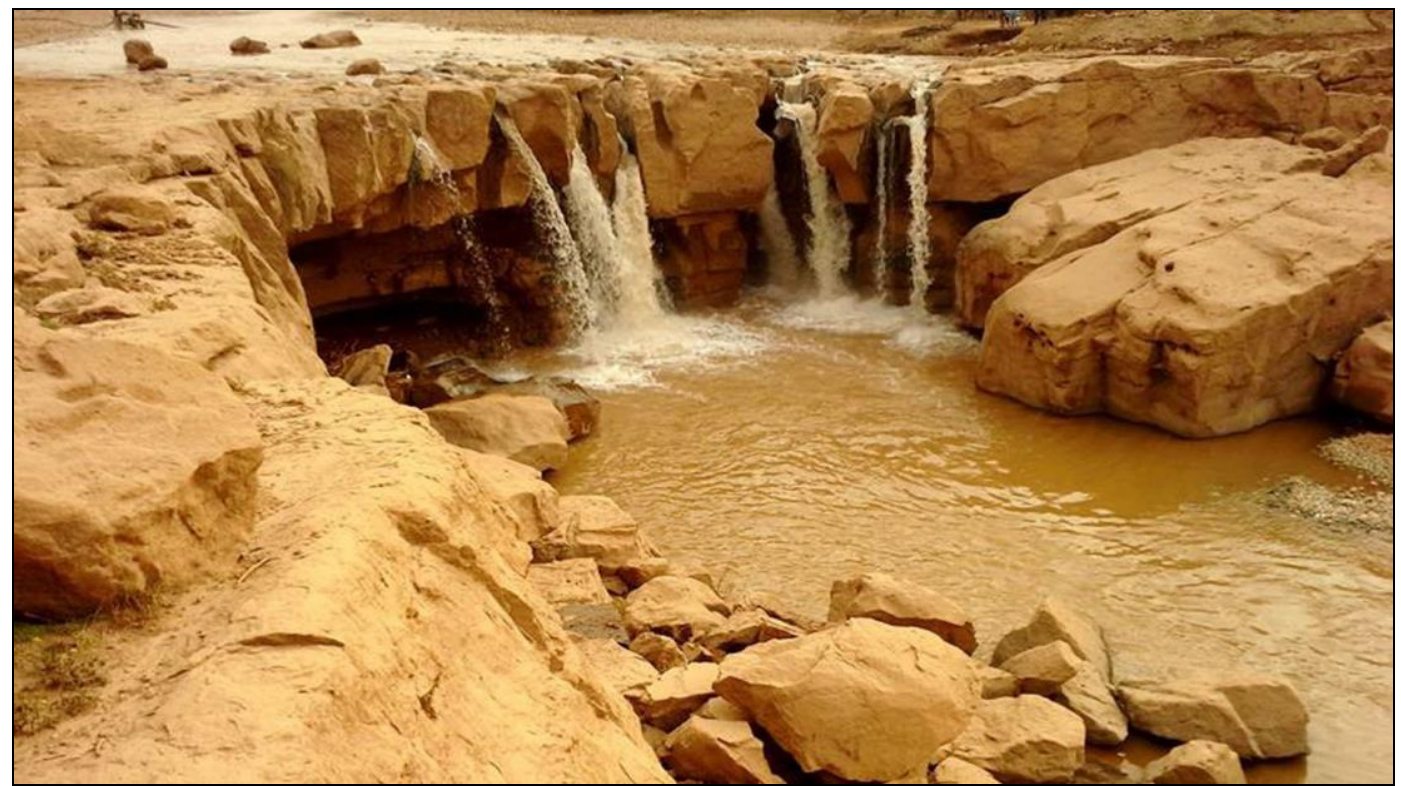

Figure 4. The view from Afrine waterfall (Source: Bahman Ebrahimi, 2013)

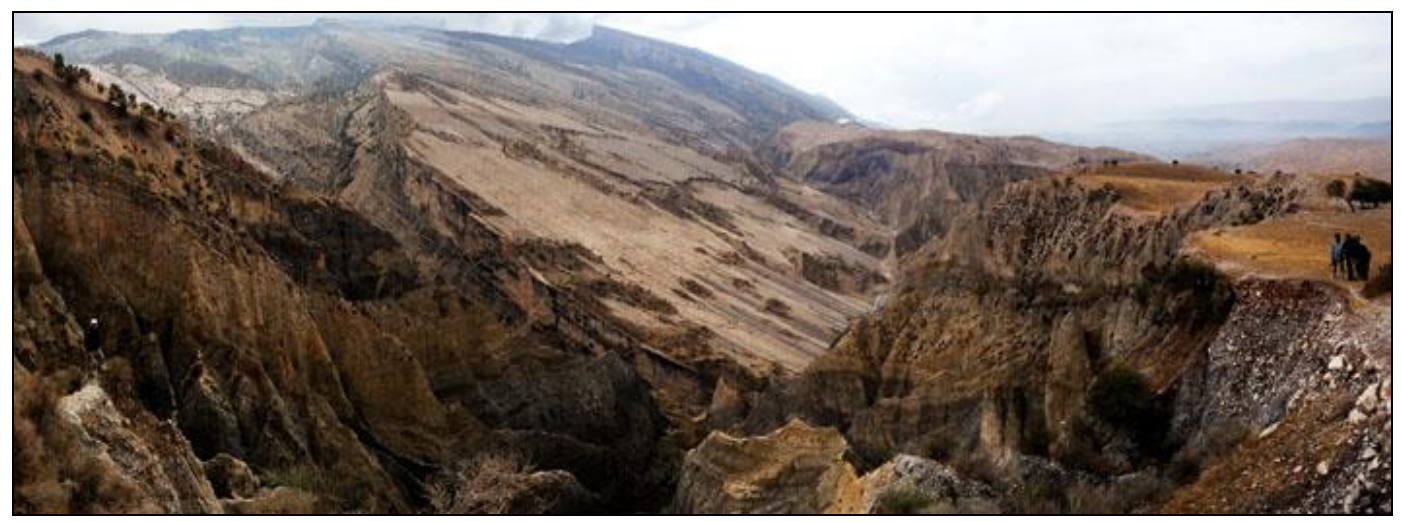

Figure 5. The view from Saymare landslide (Source: Mojtaba Yamani, 2014) 
Geomorphosites Assessment of Lorestan Province in Iran by Comparing of Zouros and Comanescu's Methods (Case Study: Poldokhtar Area, Iran)

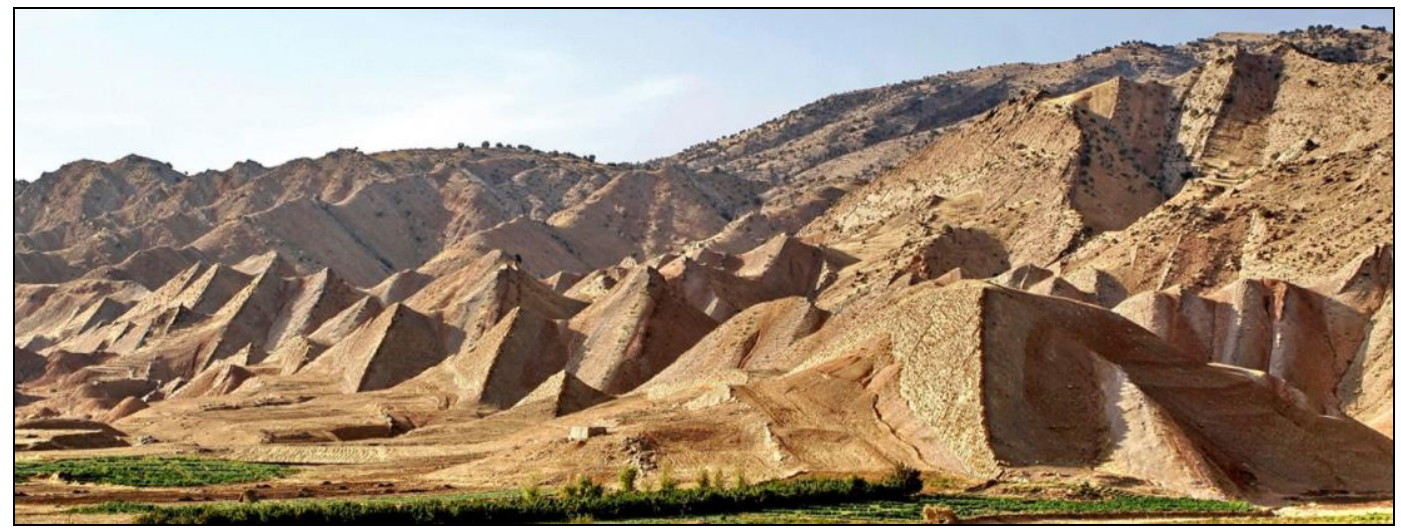

Figure 6. The view from Hogbacks (Source: Alirez AmriKazemi, 2011)

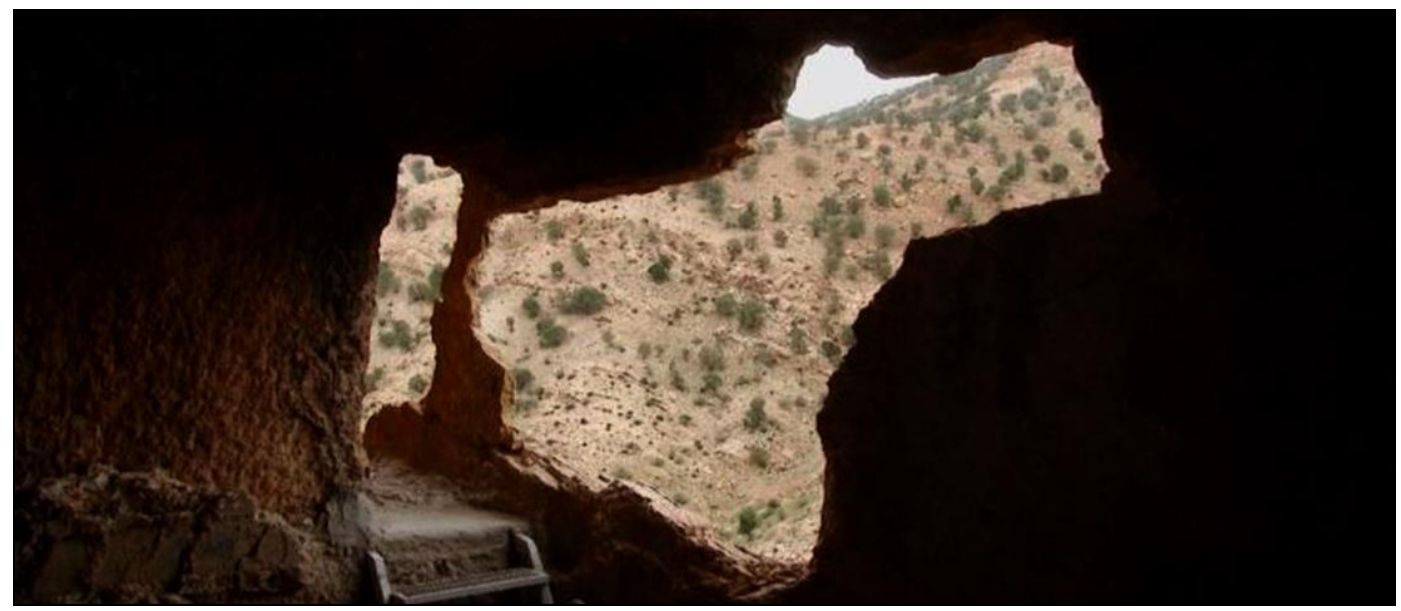

Figure 7. The view from Kowgan cave to the outside

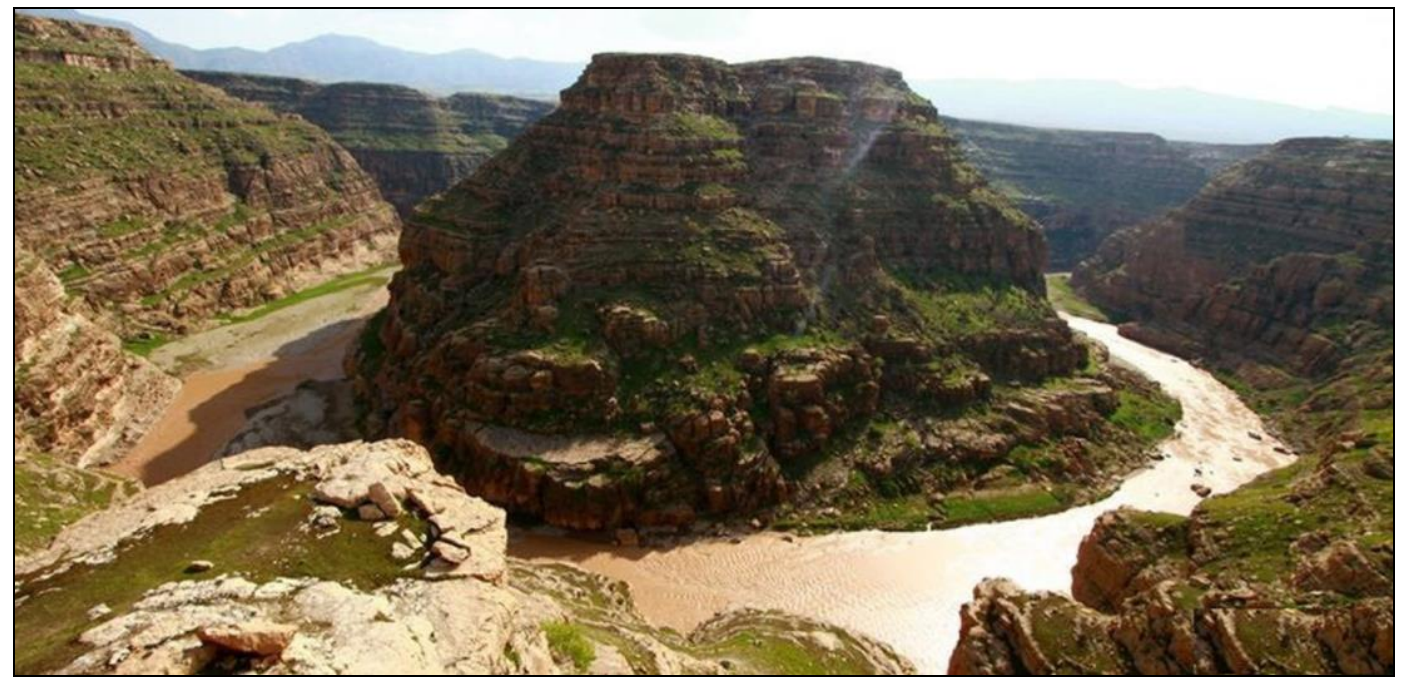

Figure 8. The view from Kashkanriver meanders, (Source: Bahman Ebrahimi, 2013) 


\section{METHODOLOGY}

For this research based on a documentary study, initial data were collected and classified that was related to the research literature (the method was selected based on geographic conditions and geotourism attractions of the region). Then the locations of 37 geomorphosites and their topographic and geological information were derived from 1:50 ooo topographic maps (1976) of Poldokhtar, Mamoulan and Bidrubeh and 1:100 ooo geological maps (1972) of Poldokhtar and Khorramabad and field work. Finally, after selecting 13 geomorphosites, based on inherent value and additional value, inventory sheet was prepared for each of them. Then during the field observations, pictures were taken of each geomorphosites and their locations were marked using GPS device and their distributions were drawn in Arc GIS software (Figure 9).

Then the evaluation of each criterion was done using special questionnaires for each method that had been completed and ranked by experts (experts in geomorphology, geology, environment, tourism management and natives). Figure 9 shows flow chart of the research process in study area.

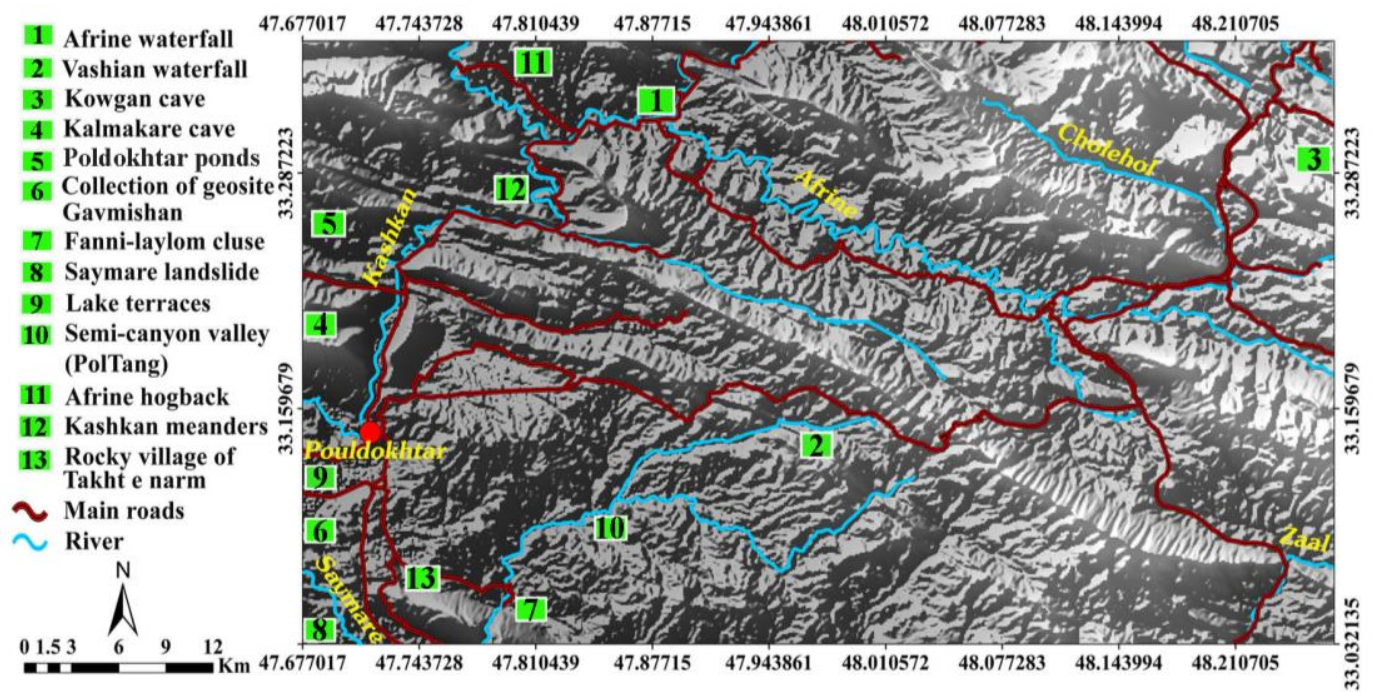

Figure 9. Geomorphosites distribution map in study area based on produced hill shade by Shuttle Radar Topographic Mission (SRTM)

\section{COMANESCU MODEL}

Generally, Comanescu model is based on 5 criteria; scientific, aesthetic, cultural, economic and management (table 2). In fact, quality assessment of perspective, scientific, cultural and or economic benefits of geomorphological sites and their tourism value forpeople, determines the capabilities application (Pralong, 2005) of geomorphosite.

The evaluation of geomorphosites according to criteria proposed in table 1 ; the total value is calculated following the formula (Comanescu et al, 2012: 57).

Equation 1:

Vtot $=($ Vsci + Vsce + Vcult + Veco $+\mathrm{Mg}) / 100$

For each of the criteria mentioned above, a score between $\mathrm{o}$ and the maximum value given to the criterion is considered, the sum for each criterion is calculated, and also the sum for all criteria, according to the above formula. 


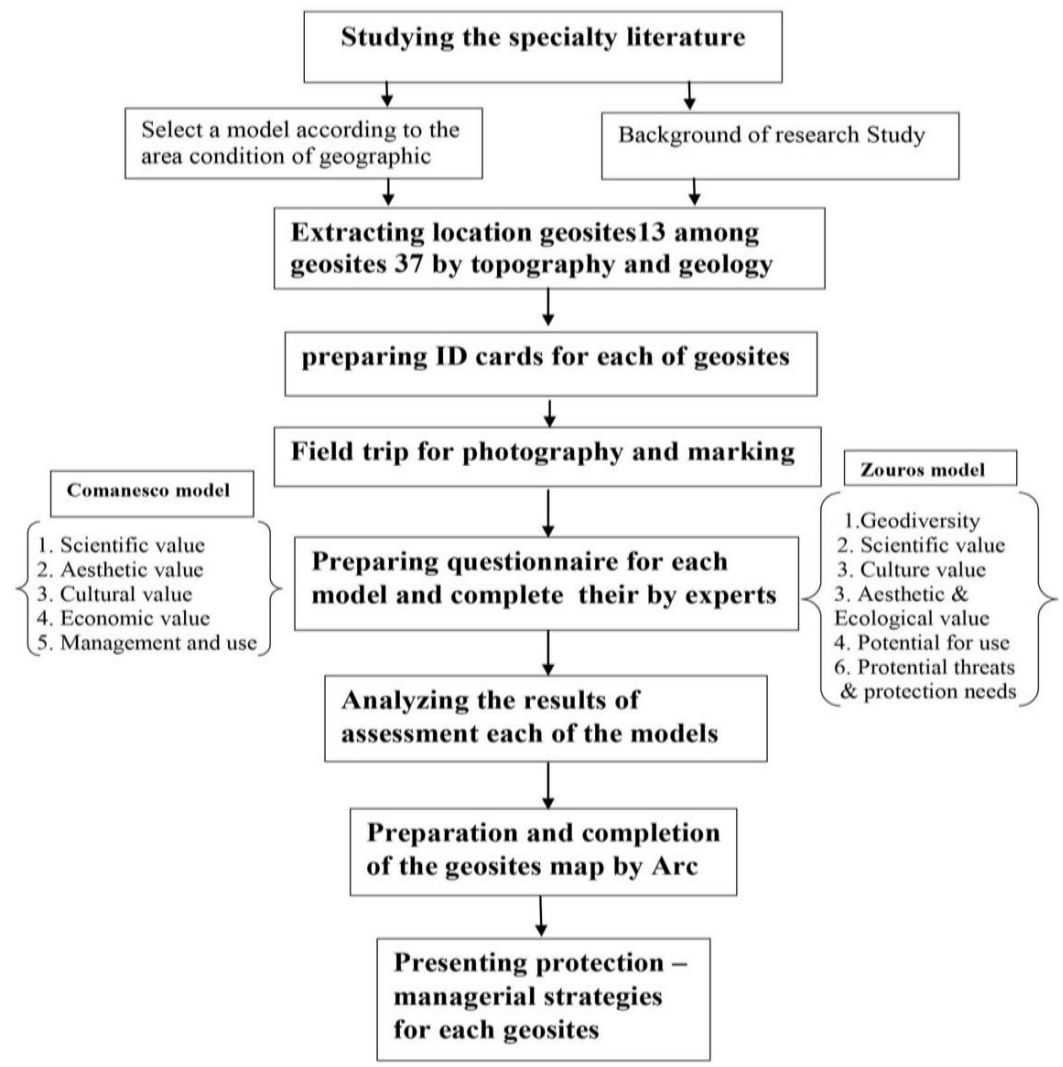

Figure 10. Flowchart of the methodological approach in study area

As we mentioned, the appreciation criteria stay the same, but the scale will differ depending on the concrete situation in the field and on the purpose and objectives of the evaluation. Thus, whether the evaluation aims firstly the scientific value, its results being used for the specialist, a higher weight will be given to paleogeographic interest, the degree of knowledge/ recognition or the ecological value. If the evaluation purpose regards educational activity, then the use in this purpose will be better measured.

In geotourism mapping, which is more interest for tourists, cultural and aesthetic values are more considered. In dedicated studies for the environmental pressure, the highest values allocated to management and economic benefit (Comanescu et al., 2012: 58).

\section{ZOUROS METHOD}

In Zouros (2007) method, several indicators have been defined for each criterion and were selected as a quantitative approach to assessment. As shown in Table 3 each indicator is given a value between $0-10$ and $0-5$, with the highest score representing the highest value. The total score of each criterion is thus the sum of its indicators (Equation 2). The total number of criteria can therefore express the quality of a geomorphosite, with 100 being the highest attainable score (Table 3).

Equation 2 (Zouros, 2007):

Geomorphosite value $=$ Scientific + Geodiversity + Ecological \& aesthetic + Cultural + Potential threats \& protection needs + Potential for use 
Mehran MAGHSOUDI, Maryam RAHMATI

Table. 2 The criteria and scores provided for evaluating geomorphosites in Comanescu method et al. $(2012,58)$

\begin{tabular}{|c|c|c|c|c|}
\hline $\begin{array}{l}\text { Scientific value } \\
20 \text { points }\end{array}$ & $\begin{array}{l}\text { Aesthetic value } \\
20 \text { points }\end{array}$ & $\begin{array}{l}\text { Cultural value } \\
20 \text { points }\end{array}$ & $\begin{array}{l}\text { Economic value } \\
20 \text { points }\end{array}$ & $\underset{\text { Management and use } 20}{\text { points }}$ \\
\hline $\begin{array}{l}\text { Paleo geographic } \\
\text { interest } \\
3 \text { point }\end{array}$ & $\begin{array}{c}\text { Visibility } \\
4 \text { point }\end{array}$ & $\begin{array}{c}\text { Cultural } \\
\text { Characteristics } \\
\text { 4 point } \\
\end{array}$ & $\begin{array}{c}\text { Accessibility } \\
\text { 4 point }\end{array}$ & $\begin{array}{l}\text { Preservation } \\
\text { Degree } \\
\text { 4 point }\end{array}$ \\
\hline $\begin{array}{l}\text { Representativeness } \\
2 \text { point }\end{array}$ & $\begin{array}{l}\text { Space structuring } \\
4 \text { point }\end{array}$ & $\begin{array}{c}\text { Historical } \\
\text { Characteristics } \\
\text { 4 point }\end{array}$ & $\begin{array}{l}\text { Infrastructure } \\
\quad 4 \text { point }\end{array}$ & $\begin{array}{l}\text { Protected sites } \\
\quad 3 \text { point }\end{array}$ \\
\hline $\begin{array}{l}\text { Rareness } \\
2 \text { point }\end{array}$ & $\begin{array}{c}\text { Color contrast } \\
4 \text { point }\end{array}$ & $\begin{array}{c}\text { Religious } \\
\text { Characteristics } \\
\text { 4 point } \\
\end{array}$ & $\begin{array}{c}\text { Yearly visitors } \\
\text { Number } \\
\text { 4 point } \\
\end{array}$ & $\begin{array}{c}\text { Vulnerability/ } \\
\text { Natural risks } \\
\text { 3 point } \\
\end{array}$ \\
\hline $\begin{array}{l}\text { Integrity } \\
2 \text { point }\end{array}$ & $\begin{array}{l}\text { Level difference } \\
\quad 4 \text { point }\end{array}$ & $\begin{array}{l}\text { Iconographic/ } \\
\text { Literary } \\
\text { representations } \\
2 \text { point }\end{array}$ & $\begin{array}{l}\text { Number of types and } \\
\text { forms of use } \\
\text { (inclusively touristic) } \\
4 \text { point }\end{array}$ & $\begin{array}{l}\text { Intensity of use } \\
\quad 4 \text { point }\end{array}$ \\
\hline $\begin{array}{c}\text { Degree of scientific } \\
\text { knowledge } \\
3 \text { point }\end{array}$ & $\begin{array}{l}\text { Landscape framing } \\
4 \text { point }\end{array}$ & $\begin{array}{c}\text { Festivals/cultural } \\
\text { manifestations }\end{array}$ & $\begin{array}{l}\text { Economic potential } \\
\text { (incomes) } \\
4 \text { point } \\
\end{array}$ & $\begin{array}{c}\text { Use of aesthetic, cultural } \\
\text { and economic value } \\
3 \text { point }\end{array}$ \\
\hline $\begin{array}{c}\text { Use in educational } \\
\text { Purposes } \\
3 \text { point } \\
\end{array}$ & & $\begin{array}{l}\text { Symbolic value } \\
4 \text { point }\end{array}$ & & $\begin{array}{c}\text { Relationship with } \\
\text { Planning policies } \\
3 \text { point }\end{array}$ \\
\hline \multicolumn{5}{|l|}{$\begin{array}{c}\text { Ecologic value } \\
\text { 3 point }\end{array}$} \\
\hline $\begin{array}{l}\text { Diversity } \\
2 \text { point }\end{array}$ & & & & \\
\hline
\end{tabular}

Table 3. The criteria and scores provided for evaluating geomorphosites in Zouros method

\begin{tabular}{|c|c|c|c|}
\hline Num & $\begin{array}{l}\text { Criteria and } \\
\text { Indicators }\end{array}$ & Assessment & Ranking \\
\hline 1 & $\begin{array}{c}\text { Scientific \& } \\
\text { educational value }\end{array}$ & & $40-0$ \\
\hline $1-1$ & Integrity & $\begin{array}{l}\text { Depends on the degree to which a geomorphological structure or process blends into } \\
\text { the site and on its level of preservation }\end{array}$ & $10-0$ \\
\hline $1-2$ & Rarity & $\begin{array}{l}\text { Depends on the number of similar sites at different levels (unique, international, } \\
\text { national, regional, local) }\end{array}$ & $10-0$ \\
\hline $1-3$ & Representativeness & $\begin{array}{l}\text { Depends on the degree to which the site is typical of a certain geomorphological } \\
\text { process }\end{array}$ & $10-0$ \\
\hline $1-4$ & Exemplarity & $\begin{array}{l}\text { Depends on the usefulness of the site for helping the general public to understand a } \\
\text { geomorphological structure or process }\end{array}$ & $10-0$ \\
\hline 2 & Geodiversity & Number of geological and geomorphological phenomena that appear at each site & $10-0$ \\
\hline 3 & $\begin{array}{l}\text { Ecological \& } \\
\text { aesthetic value }\end{array}$ & $\begin{array}{l}\text { Characterization by international designation or by national or regional legislation } \\
\text { (WHS - natural world heritage site or MAB- biosphere reserve, national park or } \\
\text { national natural monument, natural park, regional park, locally protected site) }\end{array}$ & $10-0$ \\
\hline 4 & Cultural value & $\begin{array}{l}\text { Characterization by international designation or by national or regional legislation } \\
\text { (WHS - natural world heritage site, national cultural monument, cultural landscape or } \\
\text { landscape of outstanding aesthetic beauty, regional monument, local monument) }\end{array}$ & $10-0$ \\
\hline 5 & $\begin{array}{l}\text { Potential threats \& } \\
\text { protection needs }\end{array}$ & & $10-0$ \\
\hline $5^{-1}$ & Legal protection & $\begin{array}{l}\text { The existing level of legal protection (international designation, national park or } \\
\text { monument, protected by national legislation, regional protection, poor protection, no } \\
\text { protection) }\end{array}$ & $5-0$ \\
\hline $5-2$ & Vulnerability & $\begin{array}{l}\text { Presence and magnitude of potential threats (uncontrollable risk, strong pressure, } \\
\text { moderate risk, controlled risk, poor risk, no risk) }\end{array}$ & $5-0$ \\
\hline 6 & Potential for use & & $20-0$ \\
\hline $6-1$ & Recognizability & $\begin{array}{l}\text { The level of recognition (international, national, regional, local, known only by } \\
\text { scientific community, unknown) }\end{array}$ & $5-0$ \\
\hline 6-2 & $\begin{array}{c}\text { Geographical } \\
\text { distribution }\end{array}$ & $\begin{array}{l}\text { The percentage of the space occupied by the geomorphosites in relation to the total } \\
\text { surface of the protected area }\end{array}$ & $5-0$ \\
\hline $6-3$ & Accessibility & $\begin{array}{l}\text { The level of accessibility (by a road of regional or national importance, by local road, } \\
\text { by unsurfaced road, by foot path, with permission only, no access) }\end{array}$ & $5-0$ \\
\hline $6-4$ & Economic potential & $\begin{array}{l}\text { Number of visitors per year (more than } 75.000 \text { visitors, more than } 50.000 \text { visitors, more } \\
\text { than } 20.000 \text { visitors, more than } 5.000 \text { visitors, less than } 5.000 \text { visitors, no visitors) }\end{array}$ & 5-0 \\
\hline
\end{tabular}


Geomorphosites Assessment of Lorestan Province in Iran by Comparing of Zouros and Comanescu's Methods (Case Study: Poldokhtar Area, Iran)

\section{RESULTS AND DISCUSSIONS}

The assessment results of 13 geomorphosite values in Poldokhtar area are shown in Tables 4 and 5 as shown in Comanescu method according to the equal values (20 points for all geomorphosites), the highest value has been allocated to scientific criteria, and the lowest score is related to cultural criteria. Also among geomorphosites, Kalmakare cave has the highest score (13.2 points) and Afrine hogback have achieved the lowest score (7.95).Valuations of each indicator in the Zouros method due to differences in each indicator values have been in a different way, so that the protection criterion had the lowest scores. As you can see the highest score is related to scientific criteria that certainly according to the highest Points were given to this indicator, is not surprising and the result is similar to the result of Comanescu method. It is worth mentioning that Seymare landslide geomorphosite with 78.5 points ranks the highest and rocky village of Takht e Narm with 53.25 score, had the lowest rank among other geomorphosites.

Table. 4 Results of selected geomorphosites assessment based on Comanescu method (2012) in study area

\begin{tabular}{|c|c|c|c|c|c|c|c|c|c|c|c|c|c|}
\hline 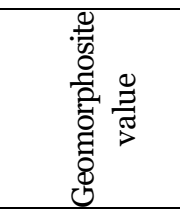 & 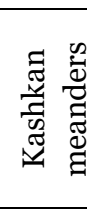 & 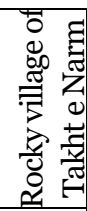 & 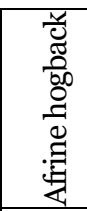 & 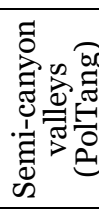 & 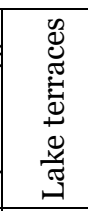 & 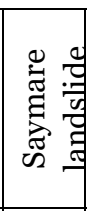 & 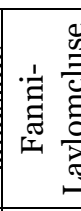 & 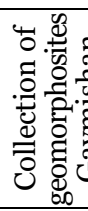 & 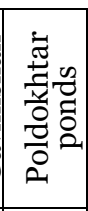 & 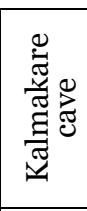 & 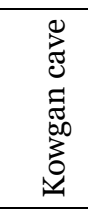 & 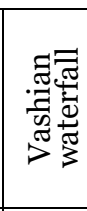 & 密莺 \\
\hline Scientific & 14.5 & $12 / 5$ & 13 & $13 / 5$ & $17 / 25$ & $16 / 5$ & $10 / 75$ & $15 / 5$ & $17 / 25$ & $17 / 5$ & $13 / 75$ & $9 / 5$ & $13 / 5$ \\
\hline Aesthetic & $14 / 75$ & $12 / 5$ & $13 / 25$ & $13 / 75$ & $13 / 5$ & $14 / 5$ & $12 / 5$ & 14 & $14 / 5$ & 11 & $11 / 75$ & $12 / 75$ & $15 / 5$ \\
\hline Cult & $3 / 25$ & $12 / 25$ & $1 / 75$ & $7 / 75$ & $5 / 25$ & $7 / 5$ & 5 & $13 / 75$ & $5 / 5$ & $16 / 25$ & $13 / 75$ & 4 & $4 / 5$ \\
\hline Economic & 7 & $5 / 25$ & $6 / 75$ & $6 / 75$ & 9 & 8 & $7 / 75$ & $10 / 5$ & 11 & 8 & 8 & $6 / 25$ & $10 / 5$ \\
\hline $\begin{array}{l}\text { Ianagement } \\
\text { and use }\end{array}$ & $4 / 75$ & $8 / 25$ & 5 & $7 / 25$ & $/ 75$ & $5 / 75$ & $7 / 25$ & $11 / 25$ & $2 / 25$ & $3 / 25$ & $12 / 25$ & $7 / 5$ & $9 / 5$ \\
\hline verage & $8 / 85$ & $10 / 15$ & 7/95 & $9 / 8$ & $10 / 3$ & //2 & $8 / 65$ & 13 & \begin{tabular}{|l|}
$12 / 1$ \\
\end{tabular} & $13 / 2$ & $11 / 9$ & 8 & $10 / 7$ \\
\hline
\end{tabular}

Table 5. Results of selected geomorphosites assessment based on Zouros method (2007) in study area

\begin{tabular}{|c|c|c|c|c|c|c|c|c|c|c|c|c|c|}
\hline 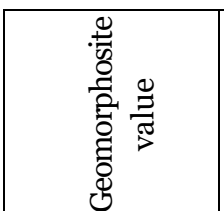 & 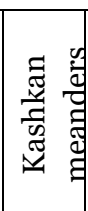 & 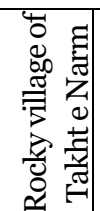 & 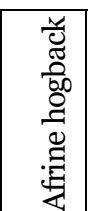 & 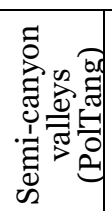 & 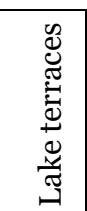 & 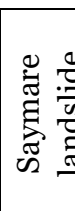 & 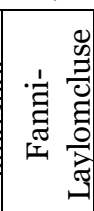 & 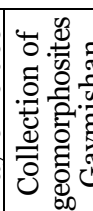 & 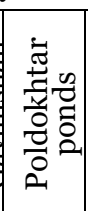 & 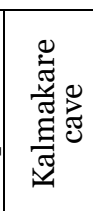 & 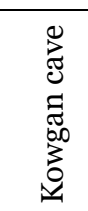 & 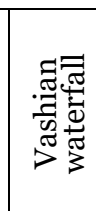 & 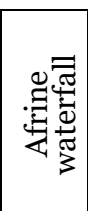 \\
\hline Scientific & 22 & $20 / 25$ & $25 / 5$ & $25 / 5$ & $25 / 5$ & 33 & $26 / 75$ & 24 & 29 & $28 / 25$ & $25 / 75$ & $24 / 75$ & $26 / 75$ \\
\hline \begin{tabular}{|l} 
Geodiversity \\
\end{tabular} & 6 & $4 / 25$ & \begin{tabular}{|l|}
$6 / 75$ \\
$6 / 2$ \\
\end{tabular} & $7 / 5$ & 8 & $9 / 5$ & 8 & 8 & $6 / 5$ & $5 / 25$ & $4 / 75$ & $5 / 25$ & \begin{tabular}{|l|}
$6 / 5$ \\
\end{tabular} \\
\hline \begin{tabular}{|l|} 
Ecological \& \\
aesthetic valu
\end{tabular} & 6 & $6 / 5$ & $7 / 5$ & $6 / 5$ & $6 / 5$ & 7 & $7 / 5$ & $5 / 5$ & $8 / 25$ & $5 / 25$ & $4 / 25$ & $5 / 5$ & $4 / 5$ \\
\hline \begin{tabular}{|l} 
Cultural \\
\end{tabular} & $5 / 25$ & $8 / 25$ & 5 & $5 / 75$ & 013 & 7 & 6 & $7 / 5$ & $6 / 75$ & $8 / 25$ & 6 & $4 / 5$ & $\tau$ \\
\hline $\begin{array}{l}\text { tential threats } \\
\text { protection } \\
\text { eds }\end{array}$ & $4 / 5$ & $5 / 75$ & 5 & $5 / 5$ & $5 / 75$ & 6 & 6 & $8 / 75$ & $6 / 75$ & $5 / 25$ & 5 & $4 / 75$ & $7 / 5$ \\
\hline Potential for use & $13 / 25$ & $8 / 5$ & $7 / 5$ & $10 / 25$ & $12 / 25$ & 16 & 9 & $14 / 75$ & $14 / 75$ & $10 / 75$ & $11 / 5$ & 10 & $\mid 15 / 75$ \\
\hline TOTAL & 57 & $53 / 25$ & $57 / 25$ & 61 & $64 / 5$ & $78 / 5$ & $63 / 25$ & $68 / 5$ & 72 & 64 & $57 / 25$ & $54 / 75$ & 66 \\
\hline
\end{tabular}

Despite having a high level of scientific point in geomorphosites, it seems that the Southwest of Lorestan province had the lowest number of visitors and therefore little development in this context is observed. Although a high scientific value for these 
geomorphosites is considered, but have had little cultural or protection values. It is possible that due to the little promotion for geotourism development in this region, less infrastructure and services have been prepared for visitors. However, the low number of visitors despite its high potential for tourism and education may also be due to poor access to some geomorphosites. Based on these results, geomorphosites of this region can be divided in to two main groups. The first group based on Comanescu method consisted of five sites with total value of high $(1,3,4,5,6)$ and the second group consists of eight sites with medium values. Also in Zouros method, the first group consists of four sites with the total value of high $(1,5,6,8)$ and the second group are 9 sites with medium values. It should be noted that the results are in accordance with Zouros study (2007) on8 selected Lesvos Island - coastal are a geomorphosites. This study emphasis on high scientific value of geomorphosites and low value for Potential application and cultural indicator. Comanescu (Comanescu et al., 2011, 2012) assess the geotourism potential of 8 geomorphosites in Pono are protected area and 16 geomorphosites in Romania Vista valley. The results of these two studies showed that cultural indicator have low value and more attention needs to be focused to these criteria it in these areas. In addition, Shayan (Shayan et al., 2014) assessed6 geomorphosits in Karaj - Chalous road and they concluded that the cultural and management indicators had the lowest points than the other indicators in this area and they are need for more attention of the authorities to these indicators in the region. A notable point in all of these studies is the high level scientific - education value of geomorphosites.

For geomorphosites management in the Poldokhtar area, some specific management actions are done for supporting and enhancing the existing sites. Comprehensive plan has been carried for identify the geotourism capabilities of Lorestan Waterfalls by Cultural Heritage, Handcrafts and Tourism Organization .For waterfalls like Afrine necessary protection acts have been described (Lorestan Cultural Heritage, Handcrafts and Tourism Organization, 2008). Among the 13 geomorphosite, only four sites $(3,4,5$ and 6$)$ were in the national registration. However, efforts must be taken for further registration of other site ssuch as 1, 8 and 13. Remarkable negative environmental consequences of tourist attraction and their increasing number in the region caused direct increasing abrasion due to continuous walking until now. Educational programs should be provide for visitors, especially students for understanding the importance of the region's geomorphosites and to further influence their insights on geological and geomorphological processes of the region.

Several management proposals are presented in order to protect and identify the geomorphosites are as:

- Reviews and revision of the laws relating to exploitation of natural resources with a conservation approach of Landform;

- Formation and strengthening the expert advocacy groups protecting landforms;

- Comprehensive monitoring and strict action against offenders;

- Continuous and effective cultural actions (especially for natives) in order to change their attitudes towards the landforms and involvement of local community for protection of geomorphosites;

- Identification of landform, based on global standard scientific methods to maintain the integrity and collection of rare samples to restoration and validity;

- Limiting and in certain cases prohibiting the as signment of natural resources to the peoples that has typical and valuable landforms (especially Poldokhtar 11 ponds);

-Assigning some geomorphosites as geographylab (geomorphology), to a large and in dependent organization in the country, such as the ministry of science, research and technology. 
Geomorphosites Assessment of Lorestan Province in Iran by Comparing of Zouros and Comanescu's Methods (Case Study: Poldokhtar Area, Iran)

\section{CONCLUSIONS}

Geomorphosites have the potential to be considered as natural and tourism resources with remarkable economic benefits, especially if they are located in protected areas. Lorestan province has been known as one of the choices of geotourism hub of Iran in 2014 according to Cultural Heritage, Handcrafts and Tourism Organization. Poldokhtar is one of the county of Lorestan provinces with high potential for geotourism development. Aim of this research was the identification and ranking of geomorphosites in this region. Two methods were used for assessment and comparing the value of geomorphosites located in the Poldokhtar area of Iran. The results showed that using two methods for comparison of areas with similar geographical conditions in order to classify the sites value is useful and can be used for better assessment of the geomorphosites. This comparison provided the design context methods with a more comprehensive indicator for similar areas. Both methods emphasize on more attention to protecting aspects of geomorphosites. In addition, the results of this study propose assigning a protected area in Saymare area. This area provides a possible of setting up a network of geomorphosites protection and monitoring activities. Additionally, promotion of local identity, the importance of tourism build infrastructure, development of new products and services locally, there by the creation of new employment opportunities, encouraging of the local economy growth and thus local sustainable development will expand.

\section{Acknowledgments}

Hereby authors wished to thank Bahman Ebrahimi, Alireza Amrikazemi and Mojtaba Yamani for offering their photos of some geomorphosites.

\section{REFERENCES}

Adriansyah, D., Busu, I., Eva, H., Muqtada, M., (2015), Geoheritage as the basis for geotourism development: a case study in Jeli District, Kelantan, Malaysia, GeoJ. Tour. Geos, 15 (1), pp. 2543.

Ahmadabadi, A., Rahmati, M., (2016), Application of geomorpholometric quantitative parameters in identification of landslide susceptible areas by using SVM model (Case study: Khorramabad-paul Zal freeway), quantitative geomorphological researches, 4(3), pp. 197-213.

Bargrizan, M., (1996), Landslide Saymare and lake depositsin Lorestan Poldokhtar southwestern, Articles collection the symposium first quaternary international, Tehran, Tehran university, Iran's UNESCO national commission publications.

Bashash, Kanzagh, R., (2000), Reading in scriptions containers attributed to the Lorestan Kalmakare cave, Administration Cultural Heritage Handicrafts and Tourism of the Iran, Cultural and tourism heritage research institute, Tehran.

Berberian, M., (1995), Master blind thrust faults hidden under the Zagros folds: active basement tectonics and surface morphotectonics, Tectonophysics, 241, pp. $193-224$.

Bloom, A., l., (1978), Geomorphology, a systematic analysis of late cenizoic landforms, New Jersey: Prentice Hall, Inc.

Carton, N., (1994), Ricerche ambientali per l'individuazione e lavalutazionedeibeni geomorfologici metodiedesempi, Il Quaternario, 7(1), pp. 365 - 372.

Comanescu, L., Nedelea, A., Dobre, R., (2011), Evaluation of Geomorphosites in Vistea Valley (Fagaras Mountains-Carpathians, Romania), International Journal of the Physical Sciences 6(5),pp. 1161 -1168.

Comanescu, L., Nedelea, A., Dobre, R., (2012), The Evolution of Geomorphosits from the Ponoare protected area, Journal of Geography 11(1), pp. 54-61.

Cope, M., A., (2016), Derbyshire geodiversity, historical geotourism and the 'geocommercialisation' of tourists: setting the context of the Castleton Blue John Stone industry, Proceedings of the Geologists' Association, $127(6)$, pp. 738-746.

Coratza, P., Giusti, C., (2005), A method for the evaluation of impacts on scientific quality of Geomorphosites. Quaternario 18 (1) volume special, pp. 306-312.

Dowling, R., K., (2013), Global Geotourism an emerging form of sustainable tourism, Czech J. Tour. 2 (2), pp. 59-79.

Fisher, W., B., (1968), The Cambridge history of Iran. The land of Iran, Oxford University Press.

Geneletti, D., Dawa, D., (2009), Environmental impact assessment of mountain tourism in developing regions: A study in Ladakh, Indian Himalaya, Environmental Impact Assessment Review 29, pp. 229-242 .

Grandgirard, V., (1997), Géomorphologie, protection de la nature etgestion du paysage. Thèse de doctorat, Faculte des sciences, Université de Fribourg. 
Henriques, M., H., Pena dos Reis, R., Brilha, J., Mota, T., (2011), Geoconservation as an emerging geoscience, Geoheritage 3, pp. 117-128.

Hooke, J., M., (1994), Strategies for conserving and sustaining dynamic geomorphological site. In: Ohalloran, D. et al. (eds.): Geological and Landscape Conservation. Geological Society, London, pp. 191-195.

Kharazian, P., (2015), Assessment of geo-tourism structure in Bojnoord City Sustainable Tourism Development, Eur. J. Sustain. Dev, 4 (2), pp. 175184.

Khosravi, L., Mousavi, S. M., (2014), Kalmakare Cave Treasure, Administration Cultural Heritage Handicrafts and Tourism of the Iran, Cultural and tourism heritage research institute, Tehran.

Maghsoudi, M., Alizade, M., Rahimiharabadi, S., Hodaearaei, M., (2013), Capability Assessment of Tourism Geomorphosites in Kavir National Park, Tourism management studies, 19, pp. 49-68.

Mahboubian, H., Sahim, H., Wilknson, G., (2003), Treasures of the mountains: The Art of the Medes, 2ened, London.

Mokhtari, D., (2015), Axioms of geomorphology and geotourism status, Geography and environmental planning, $25(1)$, pp. 91-10.

Newsome, D., Dowling, R., (2018), Geoheritage and Geotourism, Chapter 17, Elsevier Inc, pp. 305-321, DOI: http://dx.doi.org/10.1016/B978-0-12-809531-7.00017-4.

Ng, C., Y., Fung, L., W., Newsome, D., (2010), Hong Kong Geopark. In: Dowling, R., Newsome, D. (Eds.), Global Geotourism Perspectives. Goodfellow. Publishers, Oxford, pp. 179191.

Panizza, M., (2001), Geomorphosites: concepts, methods and example of geomorphological survey, Chinese Science Bulletin, 46, Suppl. Bd 1, pp. 4-5.

Panizza, M., Piacente, S., (1993), Geomorphological assets evaluation, Zeitschriftfür Geomorphologie N.F. Suppl, Bd 87, pp. 13-18.

Parhan, S., (2014), Untold of ancient treasures of Kalmakare cave, Bukhara journal, 93(15), pp.124-110Pralong, J.P., (2005), A method for assessing the tourist potential and use of geomorphological sites, Géomorphologie. Relief, processes, environnement, 3, pp. 189-196.

Pereira, P., Pereira, D., Caetano Alves, M. I., (2007), Geomorphosite assessment in and mapping. An introduction, Géomorphologie, Relief, processus, environnement, 3, pp. 177-180.

Reynard, E., Coratza, P., (2007), Geomorphosites and geodiversity: a new domain of research. Geographica Helvetica, 62, pp. 138-139.

Reynard, E., Fontana, G., Kozlik, L., Scapozza, C., (2007), A method for assessing «scientific» and «additional values» of geomorphosites, Geographica Helvetica, 62(3), pp.148-158.

Reynard, E., Panizza, M., (2005), Geomorphosites: definition, assessment geomorphological sites. Géomorphologie, Relief, processes, environment, 3, pp. 189-196.

Rivas, V., Rix, K., Frances, E., Cenderero, A., Brunsden, D., (1997), Geomorphological indicators for environmental impact assessment: consumable and nonconsumable geomorphological resources, Geomorphology, 18, pp. 169-182.

Rocha, J., Brilha, J., Henriques, M., H., (2014), Assessment of the geological heritage of Cape Mondego Natural Monument (Central Portugal), Proceeding of the Geologists' Association, 125, pp. 107-113.

Sallam, E., S., Ponedelnik, A., A., Tiess, G., Yashalova, N., N., Ruban, D., A., (2018), The geological heritage of the Kurkur Dungul area in southern Egypt, Journal of African Earth Sciences, 137, pp. 103-115.

Sallam, E., S., Fathy, E. E, Ruban, D., A., Ponedelnik, A. A, Yashalova, N.N., (2018), Geological heritage diversity in the Faiyum Oasis (Egypt): A comprehensive assessment, Journal of African Earth Sciences, 140, pp. 212-224.

Sarkarinejad, K., Ghanbarian, M., A., (2014), The Zagros hinterland fold-and thrust belt in-sequence thrusting, Journal of Asian Earth Sciences, 85, pp. 66-79.

Serrano, E., Gonzalez Trueba, J., J., (2005), Assessment of geomorphosites in natural protected areas: the Picos de Europa National Park (Spain), Géomorphologie. Relief, processus, environnement, 3, pp. 197-208,

Shayan, S., Banisafar, M., Zare, Gh., Fazli, N., (2014), Geomorphosites Sustainable Tourism Development Potential Evaluation by Emphasis on Comanescu Method (Case Study: Geomorphosites in Tourism: Karaj-Chaloos to Kandovan Tunnel), Planning and tourism development, 2(5), pp. 78-92.Yamani, M., Shamsipour, A., A, Rahmati, M., (2015), The bounding of the present and quaternary zones of climate and morphogenesis processes in Khorramabad -ZaalBridge freeway, Quantitative geomorphological researches, 2, pp. 90-103.

Zouros, N., (2007), Assessment, protection, and promotion of geomorphological and geological sites in the Aegean area Greece, Géomorphologie: Relief Processus Environ, 3, pp. 227-234.

*** (2014), Administration Cultural Heritage Handicrafts and Tourism of the Lorestan Province, Official correspondence related to the tourism hub of the country with geological survey in 2014 year.

*** (2010), Organizing project of Kowgan cave, Administration Cultural Heritage Handicrafts and Tourism of the Lorestan Province.

*** (2008), Organizing project of Lorestan waterfalls, Administration Cultural Heritage Handicrafts and Tourism of the Lorestan Province.

Submitted:

26.11.2017
Revised:

15.03.2018
Accepted and published online 18.03.2018 